\title{
New Attempts for the Histochemical Demonstration of Sulfatase Activity.
}

\author{
Hideo Takamatsu, Kikuo Mizoguchi, Mitsuru Itoh, Masakazu \\ TAKesawa and Junichi IketanI
}

(Department of Pathology, The Tuberculosis Research Institute, Kyoto University.)

As is well known, heavy metal, such as lead salt, may cause an nonspecific staining of tissue sections by incubation procedure. Lead ion is an excellent reagent to catch the sulfate ion and many histochemists tried to apply lead ions for histochemical detection of sulfatase activity. Of course in this case, non-specific staining is usually accompained with enzymatic staining. There have been another method of dye formation. But this method is unsuitable for study of substrate specificity. For this reason, we have tried some experiments to find new method which is based on the catch of sulfate ion.

\section{Experiments and Results}

(1) The first series of the experiments (Study on Alizarin dye). Explanation of the experiments: The experiments are not intended to stain any substances which are linked with sulfate ion, but quite unique meanings. Dissolves barium salt in diluted alizarin dye solution of certain concentration. And if a water solution with sulfate ion is added in the dye solution, stained precipitate of barium sulfate will appear promptly and the supernatant may become quite colorless. Instead of sulfate solution, a substrate substance for sulfatase is mixed in the solution and then if any suitable tissue sections are incubated in this mixture for several hours or more, stained barium sulfate will appear on the sites of the sulfatase activity at one step. By this method, the sites of sulfatase activity can be stained directly.

So the secondary mistake can be avoided. The concentration of the dye is so diluted not to stain the sections without enzyme activity. Alizarin Orange and Quinalizarin were proved to be suitable for these experiments. Other dyes of alizarin series are also useful. The authors prepared the dye about 0.1 per cent in $0.1 \mathrm{~N}$ ammoniac solution and diluted it with water and made hydrogen ion concentration to near neutral area. The author tested phenylsulfuric acid potassium salt, lauryl sulfate, chondroitin sulfate, indigosol, indoxyl suflate, ricinol sulfate. The stained pattern of those substrate experiments are compared.

(2) The second series of the experiments (Study of benzidine method)

As the precipitating reagent for sulfate ion benzidine is very excellent. This reagent has been used in biochemical area for long time and Ohara et al. introduced it in histochemistry. These authors tried to visualize benzidine 
sulfate with 1.2-Naphthoquinone-4-sulfonic acid. This is a reagent for amido group, and as the author described, the stained pattern is not so distinct. The present authors made two experiments for visualization of benzidine sulfate on the tissue sections.

(1)

(2)

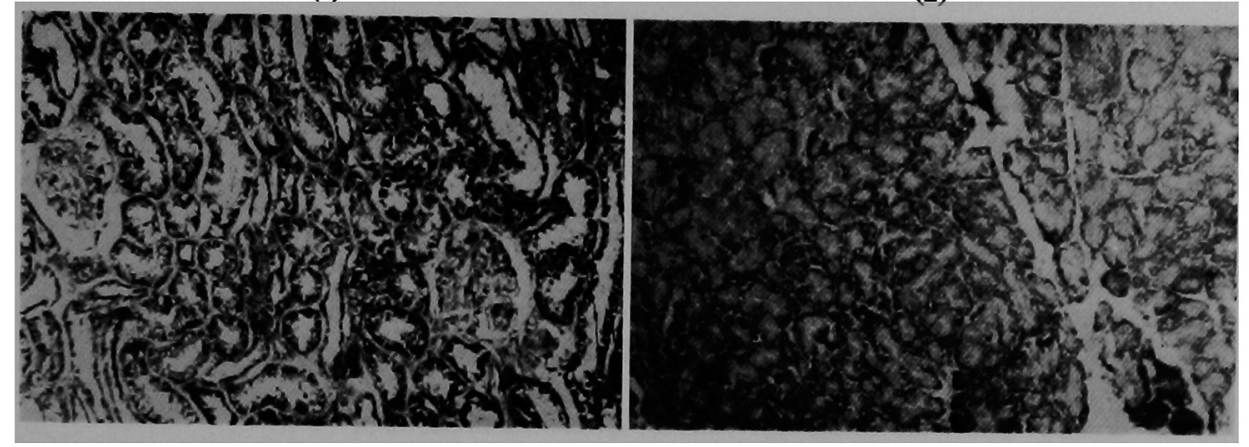

(3)

(4)

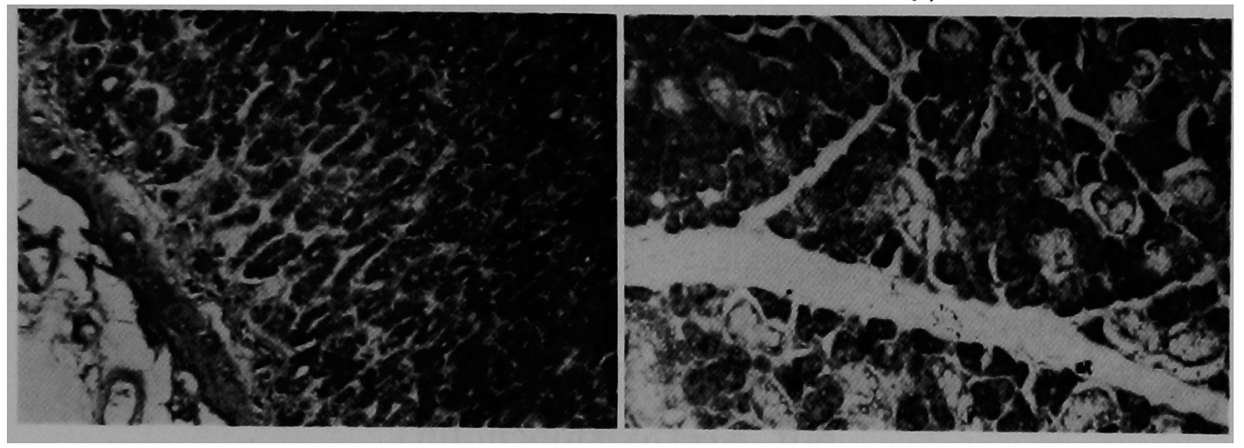

(5)

(6)

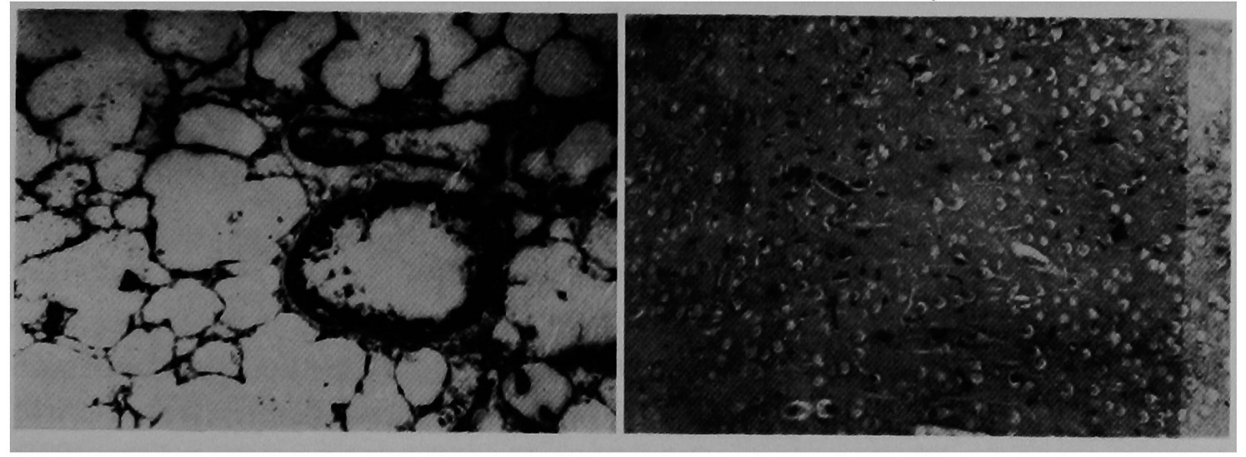

The principle of the one experiment depends on refraction of the benzidine sulfate under a refract light micorscope. According to the experiment a big crystal of benzidine sulfate showed refraction intensively but fine crystal is indistinctly. So the authors believe that this character is not suitable for histochemical purpose in general but there may be another uses for special purpose in special cases. 
The other experiment is concerned to staining property by some dyes. Extremely diluted hematoxylin solution and also diluted eosin solution can stain the precipitant and it was also proved that the same dye solution did not stain nuclei of the tissue cells.

\title{
Summary
}

For histochemical demonstration of sulfatse activity of tissue sections, some experiments were tried according to our new principles. The methods and results were reported. In compare with other methods for the enzymes, these new methods seemed to be not so excellent at present time, but the authors believe that the new principle will cause great contribution in enzyme histochemistry.

\section{Explanation of theplates}

(1) Rat kidney. Substrate is indoxyl sulfate, Quinalizarin method.

(2) Rat pancreas. Indoxyl sulfate. Quinalizarin method.

(3) Rat gastric mucosa. Substrate is Indigosol, Quinalizarin method.

(4) Rat submandibular gland. Substrate is indigosol. Quinalizarin method.

(5) Rat lung. Potassium phenyl sulfate is used as substrate. Quinalizarin method.

(6) Rat brain, substrate is phenyl sulfate. Benzidin method. Visualized with. 1.4-Naphthoquinone -4- sulfonic acid.

\section{Histochemie der Cholinesterase (fortgesetzt) über Karnovsky'sche Methode (eine Modifikationsmethode mit Acethylthiocholin)}

\author{
von \\ Akihiro Igata und Masanori Uono \\ Aus der III. Medizinischen Klinik der Tokyo-Universitat \\ (Direktor: Prof. Dr. K. Nakao)
}

Neulich hat Karnovsky über die Modifikationsmethode zum histochemischen Nachweis der Cholinesterase mit Acetylthiocholin kurz berichtet, wodurch die Fermentaktivität mit Zusatz von Ferricyankalium unmittelbar gefärbt in Sicht kommt. (J. Histochem. Cytochem. $12: 219$ letters to the editor, 1964)

Hier wurde diese neue Methode nachgeprüft und aus methodischem Gesichtspunkt durchuntersucht. Das Prinzip der Methode ist folgende. (Abb. 1) Thiocholin, das durch Cholinesterase von Acetylthiocholin abgebaut wird, beschleunigt den Reduktionsprozess von Ferri-zu Ferro-cyan Kalium, das letzter durch Kupplung mit Kupfer in der Substratlösung das unlösliche Ferrocyankupfer macht, das als bräunliche Farbe je nach der Fermentaktivität nie- 